This is an electronic reprint of the original article. This reprint may differ from the original in pagination and typographic detail.

Author(s): Pasanen, Tero

Title: Gaming the Taboo in the Finlandisation Era Finland: The Case of Raid over Moscow

Year: $\quad 2014$

Version:

Please cite the original version:

Pasanen, T. (2014). Gaming the Taboo in the Finlandisation Era Finland: The Case of Raid over Moscow. In D. Stobbart, \& M. Evans (Eds.), Engaging with Videogames: Play, Theory and Practice (pp. 121-131). Inter-Disciplinary Press.

All material supplied via JYX is protected by copyright and other intellectual property rights, and duplication or sale of all or part of any of the repository collections is not permitted, except that material may be duplicated by you for your research use or educational purposes in electronic or print form. You must obtain permission for any other use. Electronic or print copies may not be offered, whether for sale or otherwise to anyone who is not an authorised user. 


\title{
Gaming the Taboo in the Finlandization Era Finland: The Case of Raid over Moscow
}

\author{
Tero Pasanen
}

\begin{abstract}
The present article examines the first politically motivated computer game controversy in Finland that followed the release of Raid over Moscow (1984), and its subsequent review, published in the MikroBitti magazine in February 1985. The game's open anti-Sovietism and certain expressions in the review trespassed on the most notable taboo in the Cold War era Finland, and thus, the case quickly gained both interest and notoriety in the Finnish media. The events took a political turn when a leftist MP proposed a written parliamentary question concerning the distribution of the game. It triggered a chain of events that started with an unofficial Soviet entreaty to restrict the marketing and sales of the game, culminating into a diplomatic protest about recurrent anti-Soviet expressions and material presented in the Finnish media. The Soviet officials considered Raid over Moscow as war propaganda that advocated a space war against the USSR and the review as an intentional provocation that harmed the Finno-Soviet relations. The Finnish Ministry of Foreign Affairs (MFA) conducted a series of enquiries, but outdated legislation concerning preliminary inspection of computer games prevented the ban. The paper is based on a series of declassified MFA documents that handle the unofficial, political course of the controversy. The documents became open to public in 2010, after their 25 year confidentiality period expired under the freedom of information legislation. The Raid over Moscow controversy was genuinely a Finnish phenomenon. Finland's geopolitical location, its special status between the Cold War blocks, and the erstwhile tensions between the superpowers makes the case unique in the history of popular culture.
\end{abstract}

Key Words: Cold War, Finlandization, Raid over Moscow, game controversy, selfcensorship, propaganda.

$* * * * *$

\section{Introduction}

An isometric action game, Raid over Moscow (Access, 1984), was the bestselling Commodore 64 game on the Finnish game markets in 1985. The game was built around the theme of anti-Sovietism, which was one of the most fundamental taboos in the Cold War era Finland. In the game the USSR is depicted as a deceitful aggressor that attacks the United States without a warning with ballistic missiles 
carrying nuclear warheads. The game ends with the symbol of the Soviet power, the Kremlin, being reduced to a pile of ruins by the American forces.

In February 1985 a review of Raid over Moscow ignited the first politically motivated computer game controversy in Finland. ${ }^{1}$ The unique aspect of it was the diplomatic arm wrestling that took place behind the political scenes, between the Finnish Ministry of Foreign Affairs (MFA) and the Soviet officials. The present paper focuses on unofficial Soviet entreaty to restrict the marketing and sales of Raid over Moscow and diplomatic protest about recurrent anti-Soviet expressions presented in the Finnish media. It is based on a series of declassified MFA documents that became open to public in 2010, after their 25 year confidentiality period expired under the freedom of information legislation (621/1999). ${ }^{2}$

\section{The Political Context}

Finlandization, which can be defined as "process or state of affairs in which, under the cloak of maintaining friendly relations with the Soviet Union, the sovereignty of a country becomes reduced" (Laqueur 1980, 7), determined the Cold War zeitgeist in Finland. ${ }^{3}$ Adaptation of such policy meant conversion through conciliation rather than military force. The Finns considered the term pejorative as it undermined the country's non-alignment. The Finlandization has been strongly personified to the presidency of Urho Kekkonen (1956-1982) (Vihavainen 1991, Nevakivi 1996). Its heyday was between the late-1960s and the early-1980s. Finlandization has a two-fold meaning: it can be perceived as a Realpolitik doctrine or as a strategy motivated by the domestic power politics. To maintain its sovereignty under the Soviet influence Finland could not challenge its stronger neighbour. On the other hand the boundaries between the Finnish internal and foreign policies were blurred during the Cold War. Fawning on the Kremlin and the so-called east card offered Finnish politicians a way to advance their careers.

Self-censorship i.e., censorship practiced by the publisher or author, was one of the central tools of Finlandization. Salminen (1996) has divided the self-censorship of the era into categories of passive and active. The former refers to self-censorship that stemmed from the Soviet threat, whereas the latter refers to a practice motivated by internal power politics. The seeds of self-censorship were sown during the Danger Years (1944-1948) and during the 1970s the practice became endemic. Selfcensorship completely saturated the Finnish media field from broadcasting to newspapers, from non-fiction to fiction literature, and from music to cinema. In the early-1980s the Finnish media culture became less constrained and critical. Opinions about the USSR and Finnish politicians, which were not tolerated during the Kekkonen era, were now being published and broadcasted.

\section{The Controversy Commences}

The origins of the controversy can be traced to a review of Raid over Moscow, published in February -85 issue of MikroBitti -magazine, one of the early Finnish 
periodicals to focus on computers and gaming. The reviewer Aki Korhonen commented the game in a following manner: "this is an exciting national defence game, in which you must attack into the USSR before their missiles reach their targets in the United States” (MB 2/85, 67). Korhonen, who at the time was 15-yearold assistant, had trespassed on a taboo.

On February $13^{\text {th }}$ television magazine A-Studio introduced Raid over Moscow to the general public. The host ended the broadcast by summarising: "it is not a surprise where this game was developed, but must Finland always try to be Europe's Little America." ${ }^{4}$ A week later, on February $20^{\text {th }}$, Tiedonantaja (English: The Informer), a newspaper affiliated with the Taistoist movement, ${ }^{5}$ published an article, "Teaching the Children - Knocking down the Gates of Kremlin," which harshly criticized the review. Tiedonantaja described the game as a form of high tech anti-Sovietism and demanded import and distribution restrictions on such computer games. On February $21^{\text {st }}$ Ensio Laine, a MP of the leftist Finnish People's Democratic League (SKDL), put forth a written parliamentary question (KK 40/1985) that reflected similar sentiments:

What measures does the government intend to undertake on account of American CMB-games being imported to our country, of which some are targeted against our neighbour Soviet Union and the children's peace education efforts?

\section{The Political Course of the Controversy}

The controversy took an unofficial political course on February $22^{\text {nd }}$ as counsellor Konstantin Kosatshev invited Charles Murto, Director of the Office of Socialist Countries, to a meeting at the Soviet embassy in Helsinki, because of "an urgent and serious matter" (Murto 1985, 1). The choice of venue was exceptional as such meetings were normally held at the MFA premises. Murto declined at first, but agreed after consulting his superiors. Also Soviet ambassador Vladimir Sobolev had personally requested the visit.

At the embassy Kosatshev underlined the seriousness and sensitivity of the case at hand before presenting Murto a copy of the Tiedonantaja article. The Soviets considered Raid over Moscow as war propaganda that advocated a space war against the USSR, and the MikroBitti review as "one of the most flagrant anti-Soviet provocations to occur in Finland over the post-war decades." (Ibid., 2) If its marketing and sales would continue, the USSR will officially heed the attention of the Finnish government in the gravest diplomatic manner. As an example of solution Kosatshev brought up an American anti-Soviet film that was banned earlier with the contribution of the MFA. ${ }^{6}$

In his response Murto doubted that the game was specifically designed to weaken the Finno-Soviet relations, as Raid over Moscow was intended for international markets. Also there necessarily were no juridical means that could be applied to 
cases like this. He also estimated that attempts to ban the game would increase its publicity and demand. On a more personal note Murto considered it regrettable that such war games were even designed for children. Kosatshev understood these concerns, but reiterated that the USSR found the matter particularly serious and reprehensible. However he thanked the MFA for paying attention to the matter unofficially and confidentially.

In the early March the MFA officials started to conduct a series of enquiries. Antero Viertiö, a negotiating official for the Department for External Economic Relations, examined the matter from a commercial policy perspective. Viertiö pointed out that the measures to control computer games and other software were extremely challenging to implement. The aforementioned products not only played integral part in the growing computer markets and general shift towards information society, but their illegal private copying thrived due to the outdated legislation and they were declared to custom under different tariff headings. The commercial policy means to restrict the importation were also rather limited. Although the commercial treaties included a clause that enabled restrictions to be imposed based on moral arguments, such actions could have unintentional and counter-effective results. Appealing to the moral clause could open a larger public debate on whether war games were more harmful than pornography or other violent entertainment. Viertiö was sceptical whether an embargo would have desired ramifications. Restrictions could create an international controversy and only increase popularity of such war games in Finland.

Viertiö recommended the MFA to distance itself from the decision-making process, suggesting that the Ministries of Justice and/or Education should handle the matter, as "the Star Wars was the problem of the coming generation" (Viertiö, 1985, 3). Scandinavian cooperation was also pondered on. Viertiö suspected that some Swedish politicians could swallow the bait set by the Finns and sponsor regulation of deviant computer games in the Nordic Council. Viertiö also proposed investigating on if Korhonen had borrowed the phrase "exciting national defence game" or whether it was his own personal musing. Korhonen was blamed for undermining the efforts to uphold friendly Finno-Soviet relations and causing such a provocation with his inconsideration. Viertiö ends his report with an Orwellian notion: "game developers probably have - or at least should have - some sense of ethics and morals. But what happens in the players' imagination is completely a different matter. At the time being it is a place beyond laws and regulations” (Ibid., 4).

Holger Rotkirch, Assistant Director of the Department of Legal Services, surveyed juridical bases to restrict the marketing and sales of Raid over Moscow. He concluded that there were no existing legal regulations or binding treaty obligations that could be applied to resolve the controversy. Rotkirch took into consideration chapter 14 of the Finnish Criminal Code, which handled offences of treason. Its section 4a stated that a person, who publicly and purposely insulted a foreign nation with mediated material and damaged diplomatic relations to that nation, could be 
fined or penalized for the maximum of two years. However Rotkirch doubted its applicability to this matter. The act was clearly public, but proving its deliberateness would be difficult. Furthermore prosecution under the section 4a was reserved for the most egregious cases and required a specific presidential diktat. A protracted legal process could also attract extensive interest and pose even more strain to the diplomatic relations.

The larger political context of the controversy started to form in March 7, when Finnish ambassador to Moscow Aarno Karhilo send a dispatch to the MFA. He reported about a meeting with G.N. Farafonov, Director General of the Department of Scandinavia from the Ministry of External Relations (MER). Farafonov had handed a non-paper, which included a démarche ${ }^{7}$ concerning recent anti-Soviet expression of opinion in the Finnish media. The paper listed mainly written publications, including the MikroBitti article. ${ }^{8}$ The MFA was reprimanded for allowing the marketing of "the space war game" continue unhindered, regardless of the entreaty. According to the USSR these publications were provocations designed to disseminate distrust towards its politics and attempts to weaken the Finnish-Soviet relations. Such material was also in conflict with the spirit of the Paris Peace Treaties of 1947 and the Finno-Soviet Treaty of 1948. The USSR expected appropriate measures from the Finnish authorities to restrict these types of publications.

Seppo Pietinen, Director General of the Political Department, briefed the Ministry of Commerce and Industry (MCI) about the findings of the MFA enquiries. Albeit Raid over Moscow's content was offensive towards the USSR there were no means to restrict its marketing and sales. Pietinen suspected that the theme had been utilized for promotional purposes, and deplored that tensions in the international politics were exploited in children's computer games.

On March $14^{\text {th }}$, Minister of Foreign Trade Jermu Laine (Social Democratic Party) responded to the parliamentary question by stating that the MCI could only restrict and ban products that posed physical danger to children. The ministry lacked legal grounds to intervene with products that could cause psychological harm on mental development and world view. He referred to the Act on the Previewing of Video and Other Audiovisual Programmes (697/1987), which was being drafted at the time, as a possible solution to deal with similar cases. ${ }^{9}$

The political arm wrestling came into a conclusion on April $11^{\text {th }}$, as Minister of Foreign Affairs Paavo Väyrynen met ambassador Sobolev in Helsinki. In his official response to the Soviet démarche Väyrynen emphasized that all the noteworthy political parties, societal organizations and the majority of Finnish people supported the Paasikivi-Kekkonen line ${ }^{10}$ and friendly relations to the USSR. He regretted for the publications deemed anti-Soviet, but denied that they were deliberately targeted to harm the Finno-Soviet relations. Väyrynen noted that freedom of expression casted restriction on intervention with such utterances, but assured that the government attempted to influence the media. Sobolev thanked Väyrynen for the 
reply, and hoped that the mutual fostering of friendly relations between the two countries would continue in the future. Not even a small group of dissidents should be allowed to harm them. Returning to the case of Raid over Moscow once more, he hoped that Finnish authorities would take appropriate measures to deal with the matter. Sobolev quoted general secretary of the Finnish-Soviet Society (SNS) Erkki Kivimäki, who had asked in a recent televised interview: "how the Finns would feel if a computer game where Helsinki is destroyed would be marketed and sold in the USSR?” (Tolvanen 1985)

\section{Conclusions}

The first politically motivated computer game controversy in Finland occurred amidst a larger domestic societal change. The unitary culture that had evolved during the Winter War was fundamentally fractured in the mid-1980s, and the old faith towards socialism did not resonate with the younger generations, who rather identified themselves with the American popular culture and the values it conveyed. ${ }^{11}$ However the open anti-Sovietism depicted in Raid over Moscow was still a taboo and politically incorrect subject until the collapse of the USSR. From this perspective some sort of reaction from the Soviets was not a surprise, but its intensity and linkage to the Finnish treaty obligations confounded even the most experienced MFA officials (Suomi 2008).

Perhaps the most interesting aspect of the declassified MFA documents were the differing perspectives on Raid over Moscow's objectives. The Soviets underlined the external aims of the game, whereas the MFA considered them to be autotelic. The USSR perceived the game as war propaganda with three-fold objectives: 1) to propagate a space war; 2) to create mistrust towards its politics, and 3) to weaken the Finno-Soviet relations. In turn the MFA denied the allusions to weaken the diplomatic relations and perceived the anti-Sovietism as a mere marketing ploy.

But how justified was the Soviet vantage point? Unquestionably Raid over Moscow contained propagandistic elements, but to label it as war propaganda was quite far-fetching. The game reflected the confrontational attitude of the Reagan era and harnessed the biases against the USSR for marketing efforts (Jermaine 1987). Furthermore there were no indications that it was directed specifically against the Finno-Soviet relations. Hence it is reasonable to assume that the Soviet zeal to define the game as war propaganda mainly served the purpose of swaying the Finnish media, and in the process to hinder the spread of American popular culture in its sphere of influence. The Finnish traditions of censorship and self-censorship were old. Raid over Moscow was supposed to act as a precedent in the medium of digital games. Their eagerness to label the MikroBitti review as "the most flagrant antiSoviet provocation to occur in Finland over the post-war decades" also supports this reading.

The controversy treated here acts as an example for the fact that legislation is always behind the emergent forms of media. In this instance the outdated law 
provided the MFA with a reasonable cause not to react on the Soviet démarche. The valid Film Previewing Act (299/1965) was not applicable to the case as it did not even recognise interactive media. If the legislation would have been up-to-date the Board of Film Classification (VET) could have banned Raid over Moscow on the grounds of explicit violence and anti-Sovietism, as it did with Finnish director Renny Harlin's film Born American (1986) a year later. This course of action would have removed the MFA from an awkward position as VET was subordinate to the Ministry of Education. Prosecuting 15-year-old Aki Korhonen of treason was also a ruled out possibility. Raising such severe charges on the basis of mere game review would have brought the unwelcomed discussion on Finlandization back to the headlines.

The Raid over Moscow controversy was genuinely a Finnish phenomenon. It merged concerns over new media and morality with conventions of Finlandization. Finland's geopolitical location, its special status between the Cold War blocks, and the erstwhile tensions between the superpowers makes the case unique in the history of popular culture.

\section{Notes}


1 The case has been discussed earlier by Jaakko Suominen (1999), Petri Saarikoski (2004) and Juhani Suomi (2006). Finnish gaming press also briefly covered the case after MTV3 News reported on the declassified MFA documents in January 2010. Thus far the only article treating the contents of the MFA documents has been published in Finnish (Pasanen 2011)

2 All translations by the author.

3 The term itself was coined by German political scientist Richard Lowenthal in 1966 (Kullaa 2012).

4 "Little America" (Finnish: pikku-Amerikka) was a Finnish pejorative term to describe countries that excessively emulated and admired American politics and/or way of life.

5 Taistoism was the radical wing of the Finnish Communist Party with extreme pro-Soviet tendency.

6 Kosatshev could not specify the film, but probably referred to John Milius' Red Dawn, which was banned by the Finnish Board of Film Classification on October 15th, 1984.

${ }^{7}$ A protest or statement of view delivered through diplomatic channels.

8 Other sensitive topics mentioned in the paper were the Russification of Estonia, the Soviet war in Afghanistan, the Red Army's internal state and the Terijoki Government.

9 However when the Act on the Previewing of Video and Other Audiovisual Programmes (697/1987) came into effect, digital games were excluded on the basis of content and purpose.

${ }^{10}$ The Paasikivi-Kekkonen line refers to a foreign policy of neutrality.

11 Saarikoski (2004) argues that rebellion against the Finnish politicians was a major factor behind Raid over Moscow's popularity, although the sale figures were not infallible indicator of their political attitudes.

\section{Research Material}

Karhilo, Aarno. Dispatch no. 217/March 7 ${ }^{\text {th }}$ 1985. Helsinki: The Archives of the Ministry for Foreign Affairs.

Murto, Charles. Neuvostoliiton suurlähetystön vetoomus neuvostovastaisen amerikkalaisen kotimikrosotapelin mainostamisen ja myynnin ehkäisemiseksi Suomessa. Memorandum no. 196/February $22^{\text {nd }} 1985$. Helsinki: The Archives of the Ministry for Foreign Affairs.

Pietinen, Seppo. Kansanedustaja Laineen eduskuntakysely amerikkalaisen kotimikropelin maahantuonnista. Memorandum no. 21900/ March 13 ${ }^{\text {th }}$ 1985. Helsinki: The Archives of the Ministry for Foreign Affairs.

Rotkirch, Holger. Neuvostoliiton suurlähetystön vetoomus neuvostovastaisen amerikkalaisen kotimikrosotapelin mainostamisen ja myynnin ehkäisemiseksi Suomessa; poliittisen osaston muistio no. 196/22.2.1985. Memorandum no. 45/March $6^{\text {th }}$ 1985. Helsinki: The Archives of the Ministry for Foreign Affairs.

Tiilikainen, Erkki. Farafonov Suomessa ilmestyneistä, neuvostovastaiseksi luonnehdituista julkaisuista. Dispatch no. 151/March $7^{\text {th }}$ 1985. Helsinki: The Archives of the Ministry for Foreign Affairs.

Tolvanen, Taisto. Neuvostovastaisiksi luokitellut julkaisut; ulkoasiainministeri Väyrysen vastaus Neuvostoliiton demarche'iin. Memorandum no. 417/April $4^{\text {th }}$ 1985. Helsinki: The Archives of the Ministry for Foreign Affairs.

Viertiö, Antero. Kotimikropelien myynti ja mainostaminen Suomessa; Neuvostoliiton suurlähetystön reaktio. Memorandum no. 167/March $6^{\text {th }}$ 1985. Helsinki: The Archives of the Ministry for Foreign Affairs.

\section{Bibliography}

Jermaine, John. “The Carver Gang: Still at Large,” Commodore Magazine, July 1987, 74-77, 118-119.

Kullaa, Rinna. Non-Alignment and Its Origins in Cold War Europe: Yugoslavia, Finland and the Soviet Challenge. London: I.B. Tauris, 2012.

Korhonen, Aki. “CMB-pelejä,” MikroBitti, February 1985, 67.

Laqueur, Walter. The Political Psychology of Appeasement: Finlandization and Other Unpopular Essays. New Jersey: Transaction Books, 1980.

Nevakivi, Jukka. Miten Kekkonen pääsi valtaan ja Suomi suomettui. Helsinki: Otava, 1996.

Pasanen, Tero. ‘’Hyökkäys Moskovaan!” - Tapaus Raid over Moscow Suomen ja Neuvostoliiton välisessä ulkopolitiikassa 1980-luvulla.' In Pelitutkimuksen vuosikirja 2011, edited by Jaakko Suominen, Raine Koskimaa, Frans Mäyrä, Olli Sotamaa and Riikka Turtiainen, 1-11. Tampere: University of Tampere, 2011.

Saarikoski, Petri. Koneen lumo: mikrotietokoneharrastus Suomessa 1970-luvulta 1990-luvun puoliväliin. Saarijärvi: Gummerus, 2004.

Suomi, Juhani. Epävarmuuden vuodet: Mauno Koiviston aika 1984-1986. Helsinki: Otava, 2006.

__, Kohti sinipunaa: Mauno Koiviston aika 1986-1987. Helsinki: Otava, 2008. 
Suominen, Jaakko. 'Mentaalihistoriallinen katsaus digitaalisuuteen.' In Johdatus digitaaliseen kulttuuriin, edited by Aki Järvinen and Ilkka Mäyrä, 75-94. Tampere: Vastapaino, 1999.

Tiedonantaja. “Oppia lapsille - Kremlistä ovet sisään,” February 22, 1985.

Vihavainen, Timo. Kansakunta rähmällään: suomettumisen lyhyt historia. Helsinki: Otava, 1991.

Tero Pasanen is a graduate student at University of Jyväskylä, Finland. His dissertation (in progress) examines how games reflect their surrounding reality. 